International Journal of Instruction e-ISSN: 1308-1470 • www.e-iji.net

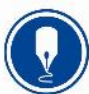

October $2018 \bullet$ Vol.11, No.4

p-ISSN: 1694-609X

pp. $159-174$

Received: 09/03/2018

Revision: 02/06/2018

Accepted: 08/06/2018

\title{
In-service Teacher Training: Problems of the Teachers as Learners
}

\section{Zeynep Ayvaz-Tuncel}

Dr., Pamukkale University, Faculty of Education, Turkey,zatuncel@pau.edu.tr

\section{Fatma Çobanoğlu}

Dr., Pamukkale University, Faculty of Education, Turkey, fcobanoglu@pau.edu.tr

Teachers need to update their knowledge and skills on curricula, psychology, and pedagogy of the learners and new research on teaching and learning; hence, they need appropriate in-service training, as well. However, the professional development practices in which they participate are mostly irrelevant to what they need and stay just in theory. Current researches criticized the inadequacy and inappropriateness of the traditional methods of teachers' professional development. In this research, the views and the suggestions of the novice teachers were investigated on in-service training, which was arranged as a part of the induction program. This research is a descriptive study and the participants consist of 494 teachers who participated in teacher induction program. A questionnaire form was used including open-ended questions. The results showed that in-service training did not make any contribution to some teachers and their personal development. The negative views on the trainers and the setting where the in-service training was conducted are other significant points for the evaluation. Therefore, it can be suggested that the planning process should be carefully carried out in order for inservice training to be effective and sustainable and the andragogy principles should be taken into account in organizing the teaching and learning process.

Keywords: teacher training, in-service teacher training, teacher professional development, teacher induction program, andragogy

\section{INTRODUCTION}

Individuals should develop themselves in line with the needs and requirements of the institutions they work in as soon as they start to perform an occupation professionally. The requirement of this developments roots in many factors such as to have the qualifications of the profession, to fulfill the deficiencies, to adapt the working place, to have a better professional performance and to advance in the career. The in-service training which can develop all these factors also increases the quality of the individual and the productivity of the institution. The concept of in-service training which is also

Citation: Tuncel, Z. A., \& Çobanoğlu, F. (2018). In-service Teacher Training: Problems of the Teachers as Learners. International Journal of Instruction, 11(4), 159-174. https://doi.org/10.12973/iji.2018.11411a 
among the competencies of lifelong learning serves to increase the life quality of the individuals through providing a professional, personal and social development.

Teachers also need to update their knowledge and skills on curricula, psychology, and pedagogy of the learners and new research on teaching and learnings; hence they need appropriate in-service training as well (Euryodice, 2004; OECD, 2005). Moeini (2008) stated that policymakers pay attention to teacher professional development to spread the necessary information and provide guidance to teachers. The emerging concern of inservice training roots in the increasing rate of technological and other changes in society. Moreover, as education has a more association with economic development, a new term appears known as "lifelong learning" which involves the continuing education (EURYDICE European Unit, 1995).

Many researches underline the important function of the in-service training in increasing the quality of education (Training, P., \& Programs In The E-, C., 2011; Theunissen et al, 1998; The European Commission, 2012; EURYDICE European Unit, 1995). Thus, developing countries allocated resources for teacher development. According to the World Bank Report (2018), a survey of 38 developed and developing countries found that 91 percent of teachers had participated in professional development in the previous 12 months. 4 Two-thirds of World Bank projects with an education component in the last decade incorporated teacher professional development.

Current research criticized the inadequacy and inappropriateness of the traditional methods of teachers' professional development (Yolcu and Kartal, 2017; Safi, 2015; Bayrakç1, 2009; Koç, 2016; Sandholtz, 2002; Popova et al., 2016; Liberman, 1995) although it has been insistently emphasized that professional development is a key point for the teacher training. Guskey and Huberman (1995, cited in Dass, 2009) opposed to a traditional form of professional development which means that teachers are treated as inadequate and incompetence and in-service training programs are there to fulfill this lack in a limited time and resources. What Skyes (1996) argues that teachers' professional development should not be limited to a couple of in-service training sessions, rather it should be a continuous process.

Darling-Hammond et al (2009, cited in Bando and Li, 2014) reviewed the related literature and pointed out 4 minimal conditions for a teacher training program in order to minimize the possible problems and make the in-service training effective: "(1) it should be intensive enough to cause a change in teacher behavior (over 50 hours), (2) it should be connected to practice, (3) it should be continuous, and (4) it must be aligned with teacher incentives." Vukelich and Wrenn (1999) also listed the requirements of a professional development process as "(1) focus on a single subject, (2) focus on participants' needs, (3) be ongoing and sustained, (4) engage participants in the pursuit of answers to genuine questions, problems, and curiosities, (5) provide for participants' meaningful engagement help participants develop collegial relationships, (6) encourage participants to reflect on their teaching." 


\section{In-service Training in Turkey}

The many EU Member States are publishing reports on increasing the quality of teacher training, focusing on the consistency between pre-service and in-service education of teachers in terms of content, pedagogy, and practice for a continuous development. What important is to train sophisticated teachers with qualified pedagogical skills and competencies in all levels and types of education. The teachers should be aware of the learners' needs and their diverse backgrounds, should have the ability to take precautions against early school leaving, and should integrate current pedagogical approaches and ICT tools with their existing knowledge (European Commission, 2015)

Continuous professional development of teachers is regarded as a professional duty in many countries which includes some legal regulations or mutual agreements (European Commission, 2013). In Turkey, in-service training programs are organized by the Directorate of Teacher Training and Development in the Ministry of National Education. In this way, teachers are provided to improve their knowledge, skills, and abilities. One of the goals in 2017-2023 Teacher Strategy Document prepared by the Ministry of National Education (MoNE, 2017) is to make the personal and professional development of the teachers continuous. In this sense, it was aimed to develop performance assessment system to determine the improvement needs of the teachers and to increase the quality of personal and professional development activities.

Pre-service education and induction programs are important as well as in-service training is. These three dimensions of the teacher training complete each other, and this case might be referred as the main provision of being a qualified teacher. In Turkey, nominees, who finish a 4-year college education training, are appointed as novice teachers after passing specific written and oral exams. Novice teachers participate in induction programs to gain more practical experience and to make their classrooms more sophisticated. As a part of the induction program conducted in 2016 (MoNE, 2015 dated Regulation of Appointment), in and out school activities and in-service training also take place. Particularly the in-service training is important in term of supporting the required professional competencies, adaptation process and applying common practices for the novice teachers.

In this research, the views and the suggestions of the novice teachers were investigated on in-service training which was arranged as a part of the induction program. This training included the topics of teaching profession, values, culture and civilization, legal regulations, MoNE policies, teaching and learning process and Turkey's educational perspective.

\section{METHOD}

This research is a descriptive study which aims to investigate the views and suggestions of the novice teachers on in-service training which was arranged in the scope of the induction program. 


\section{Participants}

The participants of the study consist of 494 novice teachers who participated in teacher induction program in Denizli in 2015-2016 academic years. The data of 332 novice teachers who responded the open-ended questions were included in the study. Of the participants, $69 \%$ were women $(\mathrm{N}=246), 31 \%$ were men $(\mathrm{N}=111)$. Participants are comprised of 54 classroom teachers (15\%), 297 field teacher (\%83) and 43 school counselors (\%2). Participants were graduated from either the faculty of education $(69 \%$, $\mathrm{N}=248)$ or other faculties $(31 \%, \mathrm{~N}=109)$.

\section{Data Collection Tool}

A questionnaire form was prepared including open-ended questions on participants' demographic properties and views on in-service training. The form was arranged based on the related literature and rearranged according to the evaluations of the experts. After a pilot study, the questionnaire was constructed for its final form. Examples from the questionnaire form are as below: "(1) Which contributions do you think these seminars make to your teaching profession?; (2) Which subjects do you wish to be included in seminars, and why?; (3) Please share your opinions about the teaching and learning process of these seminars?; (4) Please share your suggestions for these seminars to be more effective."

\section{Data Analysis}

Percentages and frequencies were calculated for the demographic properties, and the content analysis was made for the responses to open-ended questions. The purpose of the content analysis is to identify the data and revealed the realities hidden in the data. The data is coded, and then themes are constructed by uniting the similar codes (Yıldırım\&Şimşek, 2013: 259). In this study, the data were organized, coded, themes and sub-themes were constructed. The data were reported through the direct quotations.

In the current study, the data collection tool was prepared based on the quality of inservice training and the related literature, the data was computerized without any changes and the data set was analyzed by two researchers separately. The interreliability coefficient was found to be $90.9 \%$. The findings were described through direct quotations from the participants, and all the data set and analysis reports were kept in case of any confirmation need.

\section{FINDINGS}

As a result of the analysis, three themes named as "contributions to the teaching experience, practical process of the in-service training and the suggestions.

\section{Contributions to the teaching experience}

Novice teachers handled the contributions of in-service training from different perspectives. Table 1 displays the views of the novice teachers on this theme. 
Table 1

Views on the contribution of in-service training on teaching experience

\begin{tabular}{llc}
\hline Theme & Codes & f \\
\hline \multirow{3}{*}{$\begin{array}{l}\text { Contributions to the teaching } \\
\text { experience }\end{array}$} & Not contributing & 279 \\
& Gaining professional attitude and value & 116 \\
& Gaining professional skills & 249 \\
& Personal development & 11 \\
\hline
\end{tabular}

Most of the novice teachers indicated negative views on the contributions of the inservice training to their teaching profession. Some views are as; "It did not contribute much as we all know the content.. (T 124)", "I don't think that it will make any contribution. I think the topics chosen are not appropriate for my professional and personal development. The subject did not interest me anyway (T 355)", "As all the content was in theory, I don't think that it has any contribution. If some practices took place, it might be beneficial, I suppose (T 180)", "I think the seminars did not contribute to me. All the thing we already knew were repeated. We studied the topics again and again that we had learned in our college days.. (T 206)". However, a group of novice teachers shared their views that the seminars were useful in terms of gaining some professional skills: "It was pretty much beneficial to fulfill the gap in my pedagogical education. I comprehended deeply how I should behave for some specific issues in classroom management (T 136)", "I learned how to start a lesson. We learned how to cope with negative situations effecting teaching process, and an effective classroom management from our dear professors. We gained new perspectives on planning a lesson and effective time management (T 326)", "I think most of the topics in seminars were contemporary and sufficient for my professional development (T 340)", and "I think I will put into practice what I have learned about communication with students especially (T 220)".

The novice teachers who stated that these seminars had positive effects on their professional development explained that they feel ready to cope with the possible problems owing to the experiences shared throughout the process. Some quotations are as; "We have experienced some pre-learning for a system that we don't know. Experiences and ideas shared provide reactions for me against a negative situation met for the first time (T 203)", "I learned such issues as how to cope with the problems in the teaching profession, effective teaching, and classroom management (T 211)..", "It was especially impressive to listen to the experiences of experienced teachers ( $T$ 228)", "I had quite knowledgeable to solve the problems and I understood that these solutions are all practical (T 233)", "I think I will be able to cope with the future problems more easily (T 268)".

Examining the responses, some of the novice teachers stated that these seminars were effective to gain professional values and develop attitudes: "I believe that I got mature before starting to teach. I will handle positive situations more professional (T 188)", "..I think it contributed me to be a more conscious, more useful and productive teacher ( $T$ 277)", "..I think it will be useful for the issue of "What kind of a teacher should I be?" (T 254)". 
Some novice teachers think that this process improved them sophisticatedly: "In-service training was very useful for us both in content and their trainers' being experts. It contributed either professionally or personally (T 70)", "It particularly contributed to my personal development ( $T$ 97)", "The topics of the training developed me in my both professional and personal life (T 178)".

\section{Practical process of the in-service training}

Based on the theme of practical process of the in-service training, three sub-themes were named as the trainer, the environment and the teaching and learning process. Table 2 displays the views of the novice teachers.

Table 2: Views on the practical process of in-service training

\begin{tabular}{lllc}
\hline Main Theme & Sub-themes & Codes & $\mathrm{f}$ \\
\hline \multirow{4}{*}{ Practical } & The trainer & Sufficient & 62 \\
& & Insufficient & 81 \\
process & Partially sufficient & 44 \\
\cline { 2 - 4 } & The environment & Insufficient & 313 \\
& & Sufficient & 23 \\
& & Partially sufficient & 5 \\
\cline { 2 - 4 } & Teaching and & Teacher-centered & 268 \\
& learning process & Insufficient/ineffective material & 70 \\
& & Unsuitable content & 28 \\
& & Effective & 12 \\
\hline
\end{tabular}

Examining the views on the practical process of the in-service training, the differences among the expectations from the trainers are striking. While some of the novice teachers indicated positive views on trainers as being qualified and successful, some others indicated negative views on account of the fact that the trainers performed insufficient and unfavorable reactions in terms of the quality. Some positive views are as "The quality of the trainers were quite well (T 218)", "The trainers' being experts in their field were effective for us (T 59)", "Our trainers were qualified and adequate (T 46)", "It was an advantage for us to be trained by qualified experts in their fields (T 44)". Some example statements for the negative views are as below; "We took the advantage of our trainers even though they were not qualified at all (T 239)", "Most of the trainers did not even stand up, they behaved us like we were students (T 250)", "I cannot say anything about the qualifications of the trainers but the seminars were just for passing time, I think (T 254)", "I think the quality of the trainers was a matter of question. I should say that they were not good speakers and not sufficient enough (T 304)". Some of the novice teachers avoided a general comment and indicated that some of the trainers were qualified: "Some of the trainers had enough qualifications. However, it is impossible to say the same for the most (T 208)", "The quality of the trainers were changeable.. (T 212)", "I think our trainers should be separated into two groups. One was who appreciated and understood us and helped through their experiences; the other was who came just to pass the time (T 221)". 
Most of the novice teachers indicated negative views on the environment of the seminars. Particularly, the crowded classes and the ventilation is a matter of issue: "The physical conditions made the seminars difficult to pass (T 219)", "It was hot, the number of the participants was high and we were in a sleepy mood because of the continuous sitting (T 10)", "Because there were too many participants, the ventilation was bad. Moreover, it was hot and people lost their interest very quickly (T 20)", "The physical conditions were very bad. We could not even listen to the trainers because of the hot weather. It was like a torture especially the ones coming from the districts ( $T$ 187)", "The setting was bad. This can be the only thing which prevents the seminars to reach its goals ( $T$ 276)".

The novice teachers had negative experiences because the process's teacher-centered: "All the traditional trainers came and gave us the seminars. We all sit and listened. And then they told, "yes, now go and be a modern and constructivist teacher" (T 217)", "The trainers gave the seminars from the power point in a monotonous way. As the hall was so hot and crowded, we lost our concentration (T 160)", "It was as we participated in the seminars just to pass the time. The issues that were useful for my profession were handled a little. All the trainers read from PowerPoint presentations and passed the time (T 216)", "It was an atmosphere that was very boring, not comfortable and very long. It was not useful, nobody listened (T 207)".

Some novice teachers thought that the materials were insufficient and ineffective. "All the materials used was only the projection and it made us bored (T 57)", "..It was an insufficiency that any material was used except from the projection (T 119)", "The quality of the trainers was clearly a matter of question, no material was used (T 299)".

The novice teachers also indicated negative views on the content. Some teachers commented as "The process might be problematic because unnecessary subjects were repeated again and again..(T 133)", "To come to the seminar every day and repeated the same issues were boring.. (T 193)".

\section{Suggestions for the in-service training}

The novice teachers made suggestions for organizing the process and the management of the content and instruction. Table 3 displays these suggestions. 
Table 3

Suggestions for the in-service training

\begin{tabular}{lllc}
\hline Main Theme & Sub-theme & Codes & F \\
\hline & Organization & Identification of the novice teacher & 19 \\
& & Selection of the place & 63 \\
& & Selection of the qualified trainer & 82 \\
& & The period of the seminar & 225 \\
& & Distance education & 13 \\
\cline { 3 - 4 } Suggestions & Content & Topics based on need analysis & 56 \\
& & Field-specific & 57 \\
& & Personal development oriented & 93 \\
& & Professional development oriented & 297 \\
\cline { 3 - 4 } & Management of the & Basic needs & 12 \\
& instruction & Active participation & 99 \\
& & Various methods and techniques & 20 \\
& & Material & 13 \\
\hline
\end{tabular}

The novice teachers indicated that the definition of novice teacher should be clarified: "The novice teachers might be treated differently. Teachers might be felt as teachers not as students (T 212)", "First of all, we should be accepted as teachers. Our superiors should not come and threatened us like we are a child (T 217)". In addition to this, some suggestions were made for the setting of the organization, selection of the trainers and the period of the seminars. The novice teachers emphasized that the number of the participants should be less and the selection of the place is important: "Firstly these seminars should be carried out in physically well conditions, the setting should not be hot and airless (T 279)", "weather conditions and the setting choice based on the weather should be taken into consideration (T 265)". Some novice teachers underlined the selection of the trainers and told that they preferred the trainers to be academicians: "More consciousness trainers might have been selected (T 122)", "In general, the trainers were field experts and this was impressive, however, academicians from the colleges would have been more effective, I think (T 59)", "I think the trainers should be sophisticated. Academicians should be preferred or they should be extremely expert in their fields. All in all, we are teachers also and people training us should be in higher level (T 58)". Another important issue that the novice teachers insistently emphasize is the period of the training. Teachers indicated the negative situations they experienced specifically due to the long period and the timing: "I think in order these seminars to be more effective, the period should be shortened firstly. As the period was such long, the teachers got bored and they focused on the finishing time instead of the evaluation of the process (T 331)", "The process of these seminars are important. The long periods, hot weather, summer session, all of these are disadvantages. Moreover, the insufficiency of the trainers was added to those conditions, any aim was reached. All these things should be considered, I think (T 140)", "Our motivation decreased as we participated in these seminars in big halls for long periods and in hot weather, and then went to the appointed cities without any summer holiday (T 100)." Some novice teachers' suggestions for this situation is distance education: "I believe if this training was arranged as a distance education, it 
would have been more productive (T 39)", "It would have been more effective and useful if it was a distance education (T 41)”.

While some of the novice teachers underlined the choice of topics under the sub-theme of "content", the others indicated that the content should be arranged based on the fields. Some significant statements are: "I think teachers should be trained according to their study field. All in all, every field needs different issues. Their expertise is different. I think it does not make any sense to expect a usefulness after a unique education ( $T$ 318)", "I think, to be more effective, presentations and workshops should be arranged based on the field (T 172)", "The views of the novice teachers might have been asked, distance education could have been arranged, and each one could have preferred the training he wants (T 69)", "The topics and the trainers should be determined more sensitively via various analysis ( $T$ 153)." Furthermore, the novice teachers suggested various seminars such as drama, theatre, diction, anger management, psychology and body language that support their personal development to be included in the seminars: "I want a more emphasis on personal development issues. We need this more both as a teacher and an individual indeed (T 70)", "More importance might be given to personal development. I would have preferred an anger management seminar (T 176)", "Maybe; there might have been some issues which are supportive for the personal development of the teachers and increasing the self-confidence (T 239)". Professional development is another important issue under the sub-theme of the content. The novice teachers suggested that such topics which can improve their professional as classroom management, the arrangement of the instruction, legal regulations, making projects, counseling, special education, and communication: "Issues which contribute to the teaching profession and which are useful in the classrooms should take place. Issues as activities, materials, classroom management, communication (T 216)", "I wish more time was spent for the topics of classroom practices, preparing materials, classroom management, and in-school activities. I think we need to know these topics more in our first years (T 255)", "New approaches to education. Designing and using materials. There would have been practices which we could improve ourselves in effective communication (T 263)", "Much more and more effective presentations might have been made in the issues of hearing impaired or mental disorders. Just in order to be aware of such students if there is any in my future class (T 47)", "I think every teacher should be more sensitive to the education of mental disorders (T 189)", "Sample projects practices and brainstorms might have been implemented with the novice teachers. Course books might be examined (T 92)".

Considering the codes under the sub-theme of "the management of the instruction", while some teachers drew attention to the basic needs in the practice period, most of the others indicated that the process should be with an active participation, practice-oriented and rich in materials: "..this training might be more meaningful and effective with the active participation of the novice teachers. We all sit and sometime after it is intolerable to listen in a fixed position like this (T 291)", "The process of the seminars should have been the one in which listeners also actively participated and shared their opinions rather the presenters just talked and left (T 5)", "the quality of the trainers and the materials should be improved. Informing should be done with a rich presentation. 
Possibilities should be created for the listeners' active participation (T 107)", "New instructional methods and techniques which are attractive for the novice teachers might take place in the seminars (T 248)".

\section{DISCUSSION AND CONCLUSION}

Saiti and Saitis (2006) underlined the significant contribution of the in-service training to various areas such as the education policy, maintenance of the educational needs of teachers and students, and the mutual relationship between the school and its environment. Nevertheless, huge amounts of resources are being spent by the governments for in-service training. Moreover, each country has its specific in-service teacher training programs, and probably many of them are ineffective (Popova, Evans, Arancibia, 2016). The current research revealed that in-service training did not make any contribution to some novice teachers. Similarly, Huhtala and Vesalainen (2017) found that teachers need and request more training and most of the in-service training organized in Sweden is irrelevant from the teachers' need. The possible explanation for the views that the process did not make any contribution is lack of a careful need analysis while planning the training. According to Moeini (2008), in the planning process of an in-service training, need analysis is usually disregarded which causes the incorrect usage of time, money and human resources, and also leads to decrease the motivation and excitement of the participants. The in-service training programs which the governments organized do not prefer to focus on existing knowledge of the teachers and their improvement; instead, they generally concern how the teachers can be trained about what they need to know. This kind of perspective is undoubtedly ineffective as it ignores the needs and the existing beliefs of the teachers which are essential for a successful professional development (Hargreaves, 1992; Fullan, 2001). As Speck and Knipe stated, teachers do not want any kind of training about their profession which is enforced by the superiors (cited in Bayrakçı, 2009).

Another possible explanation for the negative perception of the contribution of the process might be that teachers are considered as the sources of the knowledge rather than active participants (Lieberman, 1995; Lieberman\&Miller, 1990 cited in Sandholtz, 2002). In his study, Karakaya (2004) suggested that most of the Turkish teachers do not consider themselves as independent teachers and instead of focusing on professional development, they do much of the bureaucratic requirements imposed by the government. This kind of training approach is problematic in the way that teachers need to know what the authority wants them to know (Lieberman \& Miller, 1990). In the traditional view of in-service training, there is a specific method that teachers are required to learn and adapt and little interaction occurs among the teachers (Sandholtz, 2002). However, professional development and communication should be taken into account together as inseparable parts of the training. In-service training programs should be carried out effectively in which trainers and teachers can work collaboratively instead of including just lectures. This approach might lead to understand the teachers better, analyze their teaching practice and provide them a more effective and significant professional development (Park et al., 2007; Angelides, 2002; Bardakç1, 2009). 
Results show that the in-service training was effective in terms of providing the teacher's professional skills, attitudes, and values. It is important for the training given by the experienced professionals in the process of gaining professional skill and attitude. In the current research, participants evaluated the trainers based on their contributions to the process. Many variables such as the quality of the trainers, their professional experience and communication styles affect the in-service training process. Bayrakçı (2009) asserted that the experienced professional trainers in education and teaching, in particular, should be included in the planning process of in-service training programs. However, according to Yolcu and Kartal (2017), people who are accepted as experts make the instructions in training programs, and this approach feeds the traditional acceptance that learning is basically the transmission of the information. Similarly, Safi (2015) found out in Afghanistan, one of the handicaps for an effective in-service program is the lack of professional trainers. In contrast, the training process should be transformed into a sharing platform of the experiences in curriculum, instruction, and measurement. The teachers should be trained by the experts of contemporary issues which are brand new for the teachers.

The current research concluded that the in-service training did not contribute to the personal development of the teachers. In a report by EURYDICE European Unit (1995) in-service training is stated to meet the teachers' not only professional but also personal needs. As Avalos (2011) underlined, a teacher professional development process includes both cognitive and emotional improvement. In this sense, an individual should be supported in the scope of pre-service and in-service activities. The participants also indicated the lack of support to the personal development in the suggestion section. Whereas, a qualified in-service training might contribute to the development of the teachers in multiple perspectives if it prevents just carrying out the planned purposes. Based on the teacher professional competency revised by The Ministry of Education (2017), professional knowledge, skills, attitudes, and values are also emphasized. Mikkola (2012, p. ix) also underlines the moral and social dimensions of teacher qualifications. She mentions four different sub-areas: content knowledge, expertise in learning and teaching, social and moral competence, and the multifaceted skills that are involved in practical school work (cited in Huhtala\&Vesalainen, 2017). Furthermore, Niemi(2015) pointed out the importance of pre-service and in-service education in developing teacher proficiency which is a key point in co-operation, collaboration and networking in and outside the school.

The negative views on the setting where the in-service training was conducted is another significant point for the evaluation of the training. The place of the training was evaluated in terms of suitability, physical and social facilities, and also the number of the participants and the weather conditions. This revealed that the conditions of the training place should be carefully considered apart from many variables. According to Özer (2004), the places chosen for the in-service training should not only be equipped with the essential learning materials but also be the appropriate places for the adult trainees. This is because the properties of the learning environment play an important role in active participation as it directly affects the teaching and learning process. In his review of adult learning theories Smylie (1995) identified specific conditions that 
encourage the learning process in the workplace: (1) opportunities for individuals to work with and learn from others on an ongoing basis; (2) collaboration in group work and learning; (3) chances to work with and learn from others of similar position; and (4) variation, challenge, autonomy, and choice in work roles and tasks (cited in Sandholtz, 2002). In the current research, teachers stated that the materials were either insufficient or ineffective. However, the usage of materials in teaching and learning process support the various learning ways through concretion. What's more, as in-service training is a type of adult education, it is sensible to consider the psychological and pedagogical features of the adult education (Myloka, 2017).

A significant finding of the current study is that participants referred the teaching and learning process of the in-service training as teacher-centered. According to Sandholtz (2002), in many of the traditional in-service training teachers just sit silently and no trace of collaboration can be followed in the sessions. Nevertheless, just as their students, teachers also need a learning environment which they can actively participate in and work with their peers collaboratively. Professional development environments should also consider the needs of each individual. It is extremely inconsistent to employ teacher-centered practices in professional development attempts with the current educational approach carried out in Turkey which is constructivism. Particularly, considering the modeling role of the teacher in gaining professional attitude and skills, this inconsistency is a huge obstacle to actual the aims of the education. On the other hand, trainers might have employed teacher-centered practices because of the unfavorable conditions and a huge number of participants.

Some of the in-service teacher training might focus on the usage of one specific technology or on the introduction of an implementation. But the in-service training in the current study had an extensive content which might lead to an overlapping throughout the process. In order to prevent this, purposes should be clearly identified in the planning process and the content should be limited based on the purposes. Besides, trainers can coordinately work and cope with the negative situation through this. The EU report (2015) underlies the unity of the content, pedagogy and the practice in performing the purposes of in-service training for both the participants and the trainers. Moreover, it is the necessity to employ a sophisticated and qualified staff in all levels and fields of education.

In the current study, the participants also made some suggestions for the in-service training process such as effective time planning in the organization of the training, a professional skills-oriented content preference and an active participation in the training process. The views and the suggestions of the participants are significant data to evaluate an implementation. To reflect the revisions through scientific feedbacks provide the implementations to be more qualified. Furthermore, it provides the continuity of the implementation and supports a quick problem-solving process to meet the need rooted in changing situations. As stated by Bayrakçı (2009) and Koç (2016), lack of provision for feedback and a systematic in-service training model are the primary problems of in-service training practices in Turkey. 


\section{RECOMMENDATION}

This study emphasized that in-service training which has a significant role in teacher training should become functional by moving away from a traditional approach which is based on the transmission of the knowledge. The teacher has a key role as a practitioner of the educational reforms. In this sense, teacher learnings should be taken into consideration as well as student learning.

The planning process should be carefully carried out in order for in-service training to be effective and sustainable. Similar to the curriculum development process, in-service training should be planned systematically, as well. The needs of the participants should be carefully analyzed and purposes should be determined according to these needs.

The content should be chosen as contemporary and practical. The development of skills and knowledge should be integrated to gain attitudes and values in a holistic way. In addition to how and what to teach, the knowledge of who is teaching and who is being taught is also important. The content should include the facilitators of learning and human development.

The andragogy principles should be taken into account in organizing the teaching and learning process and the activities required active participation should be designed. The quality of the trainers, the features of the environment and the period of the training are also important variables in reaching the goals effectively.

In the evaluation process, the level of goal achievement should be considered in terms of the reflection of the practices in the classroom. Participants should also take place in planning and evaluation process of their own trainings. Feedbacks should be taken into account for the future in-service training.

A more scientific and current process might be employed via a collaboration with teacher training institutions and teacher trainers throughout all phases of in-service education. Apart from this, a continuous dialogue between the researchers, scientists, and teachers leads to update their knowledge.

An in-service training is an expensive investment in terms of time, money and facilities. Thus, it is advisable to examine this investment scientifically and to search its sustainability and the effects on the classroom activities.

\section{REFERENCES}

Avalos B. (2011). Teacher professional development in Teaching and Teacher Education over ten years, Teaching and Teacher Education, 27(1), 10-20.

Bando, R. \& Li, X. (2014). The effect of in-service teacher training on student learning of English as a second language. Washington: Inter-American Development Bank Working Paper Series No: IDB-WP-529. 
Bayrakc1, M. (2009). In-Service Teacher Raining in Japan and Turkey: a Comparative Analysis of Institutions and Practices, Australian Journal of Teacher Education, 34(1), $10-22$.

Dass, P. M. \& Yager, R. E. (2009) Professional Development of Science Teachers: History of Reform and Contributions of the STS-Based Iowa Chautauqua Program. Science Education Review, 8(3), 99-111.

EURYDICE (1995). In-service training of teachers in the European Union and the EFTA/EEA countries. European Unit, Belgium.

EURYDICE (2004). Keeping teaching attractive for the 21st century. European Unit, Brussels.

Guskey, T. R. \& Huberman, M. (1995). "Introduction.” In: Guskey, T.R. and Huberman, M. (Eds) Professional Development in Education: New Paradigms and Practices. New York: Teacher College Press, pp. 1-6.

Huhtala A. \& Vesalainen, M. (2017). Challenges in developing in-service teacher training: Lessons learnt from two projects for teachers of Swedish in Finland. Apples Journal of Applied Language Studies, 11(3), 55-79.

Karakaya, S. (2004) A comparative study: English and Turkish teachers' conceptions of their professional responsibility, Educational Studies, 30(3), 195-216. DOI:10.1080/0305569042000224170

Koç, E. M. (2016). A General Investigation of the In-Service Training of English Language Teachers at Elementary Schools in Turkey. International Electronic Journal of Elementary Education, 8(3), 455-466.

Liberman, A. (1995). Practices That Support Teacher Development: Transforming Conceptions of Professional Learning. The Phi Delta Kappan, (8), 591.

Ministry of National Education [MoNE]. (2015). Regulation of Appointment, Ankara: Turkey.

Ministry of National Education [MoNE]. (2017). Teacher Strategy Document 20172023, Ankara: Turkey.

Moeini, H. (2008). Identifying Needs: A Missing Part in Teacher Training Programs, International Journal Of Media, Technology And Lifelong Learning, 4 (1).

Mykola, S. (2017). In-service teacher trainıng courses: organızatıonal components. Naukovì Zapiski Ternopil's'kogo Nacìonal'nogo Pedagogičnogo Unìversitetu Imenì Volodimira Gnatûka. Seriâ: Pedagogika, 0 (2), 121-129. doi:10.25128/24153605.17.2.17

Niemi, H. (2015). Teacher professional development in Finland. Psychology, Society, \&Education, 7 (3), 279-294. 
OECD (2005). Teachers matter. Attracting, developing and retaining affective teachers. OECD Publications, France.

Özer, B. (2004). In-service training of teachers in Turkey at the beginning of the 2000s, Journal of In-service Education, 30 (1), 89-100.

Popova A., Evan, D. K. \& Arancibia V. (2016). Training Teachers on the Job, What Works and How to Measure It. Background Paper to the 2018 World Development Report, Policy Research Working Paper 7834

Safi, S. (2015). In-service Training Programs for Schools Teachers in Afghanistan: Teachers' Views about effectiveness of the In-service training. Networked Digital Library of Theses \& Dissertations, EBSCOhost (accessed January 5, 2018).

Saiti, A \& Saitis, C. (2006) In-service training for teachers who work in full-day schools. Evidence from Greece , European Journal of Teacher Education, 29(4), 455470. DOI: 10.1080/02619760600944779.

Sandholtz, J. H. (2002). Inservice training or professional development: contrasting opportunities in a school/university partnership. Teaching and Teacher Education, 18 (2002) 815-830.

Sezer, B., Karaoğlan-Yılmaz, F.G. \& Y1lmaz, R. (2017). Comparison of Online and Traditional Face-to-Face In-Service Training Practices: An Experimental Study. Çukurova Üniversitesi Eğitim Fakültesi Dergisi 46(1), 264-288.

Sykes, G. (1996). Reform of and as Professional Development. The Phi Delta Kappan, (7), 464.

The European Commission (2013). Key Data on Teachers and School Leaders in Europe. 2013 Edition. Eurydice Report. Luxembourg: Publications Office of the European Union.

The European Commission (2012). Supporting the teaching professions for better learning outcomes. Commission staff working document. Strasbourg, SWD(2012).

The European Commission (2015). New priorities for European cooperation in education and training. Commission staff working document. Brussels, SWD (2015).

Theunissen, M. \& Veenman, S. (1998). Interorganisational Networks in the Domain of In-Service Teacher Training. Reports, Catholic Univ., Nijmegen (Netherlands).

Training, P., \& Programmes In The E-, C. (2011). Teachers as Lifelong Learners: Case Studies of Innovative In-Service Teacher Training Programmes in the E-9 Countries.

Vukelich, C. \& Wrenn, L. C. (1999) Quality Professional Development: What Do We Think We Know?, Childhood Education, 75(3), 153-160. DOI: $10.1080 / 00094056.1999 .10522003$ To link to this article: https://doi.org/10.1080/00094056.1999.10522003 
Yıldırım, A. \&Şimşek, H. (2013). Sosyal bilimlerde nitel araştırma yöntemleri (Qualitative research methods in social sciences). Ankara: Seçkin Yayıncılık.

Yolcu, H. \& Kartal, S. (2017). Evaluating of In-service Training Activities for Teachers in Turkey: A Critical Analysis. Universal Journal of Educational Research, 5(6): 918926, 2017.

Arshad M. (2005). Use of Technology in Malay Language Literacy Education. Masalah Pendidikan, 28. pp. 269-278. ISSN 0126-5024.

Aris, B., Yahaya, N., Harun, J., \& Tasir, Z. (2000). Education Technology. Skudai: University of Teknologi Malaysia.

Azhar M. (2007) Level Of Professionalisme Among Islamic Education Trainees In Practical Teaching (unpublished Masters thesis). Universiti Teknologi Malaysia, retrieved September 2011 from eprints.utm.my/4276/1/75215.pdf 